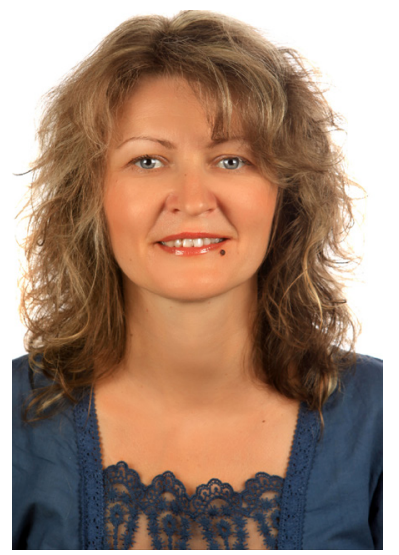

Роксоляна Зозуляк-Случик, кандидат педагогічних наук, доцент кафедри соціальної педагогіки та соціальної роботи, ДВНЗ «Прикарпатський національний університет імені Василя Стефаника» (м. Івано-Франківськ, Україна)

Roksolyana Zozulyak-Sluchyk, $\mathrm{PhD}$ in Education, Associate Professor, Department of Social Pedagogy and Social Work, Vasyl Stefanyk Precarpathian National University (Ivano-Frankivsk, Ukraine) zozulyak_roksolyana@ukr.net ORCID ID: 0000-0001-6066-590X

Удк 374.4:364-051

\title{
СУЧАСНІ ПРИНЦИПИ ФОРМУВАННЯ ПРОФЕСІЙНОЇ ЕТИКИ МАЙБУТНІХ СОЦІАЛЬНИХ ПРАЦІВНИКІВ В УНІВЕРСИТЕТАХ
}

\begin{abstract}
Анотація. У статті автор розкрив сутність дефініції «принцип». Визначив та детально обґрунтував роль сучасних принципів у формуванні професійної етики майбутніх соціальних працівників в університетах, які стали підґрунтям розроблення педагогічної системи професійної підготовки фахівців. У дослідженні виокремлено специфічні принципи: професійно-аксіологічної спрямованості; єдності теорії професійної етики та моральної практики (фахової моральності); системності формування професійної етики; міждисциплінарністі у формуванні професійної етики; єдності моральної свідомості й моральної діяльності; комплементарності; інтеграції і взаємовпливу етичного та професійного знання; проектування особистісної траєкторії формування; морально-етичної рефлексивної спрямованості процесу навчання студентів спеціальності «Соціальна робота»; морального вибору; фасилітації; академічної доброчесності.

Розглянуто загальнодидактичні принципи діяльності університетів: об'єктивності, зв'язку теорії з практикою, систематичності, наочності й різноманітності методів, міцності засвоєння знань, умінь і навичок. Також у роботі проаналізовано загальнопедагогічні принципи: гуманізації та демократизації, науковості, наступності і послідовності, безперервності, динамічності, особистої активності.
\end{abstract}

Ключові слова: професійна етика, соціальний працівник, університет, специфічні принципи, загальнопедагогічні принципи.

\section{MODERN PRINCIPLES OF FORMING THE PROFESSIONAL ETHICS OF FUTURE SOCIAL WORKERSAT UNIVERSITIES}

Abstract. The formation of specialists in the social sphere at the present stage of Ukraine's formation puts radically new demands and challenges in front of the educational sphere. Higher education is responsible for it. Special attention should be paid to the new research approaches to the theoretical substantiation of the specific principles of the formation of professional ethics and morals O. Dub, A. Kalensky, M. Mikhnyuk, L. Moskalova, O. Ponomarenko, N. Sopneva, L. Horuzhoy and others who form the basis of a professional -ethical reflection in the ethics-applied field.

The article reveals and substantiates specific, general pedagogical and general-didactic principles of the process of formation of professional ethics of future social workers at universities.

Social work as a type of professional activity is also built on specific principles, such as humanism, social responsiveness, communicative, variability of social assistance, client centricism, personal approach, trust in the client, and maintaining customer trust in a social worker, justice, tolerance, modality (flexibility), permanence (continuity), competence, confidentiality, mediation, etc.

Formation of professional ethics of future specialists in social work in the educational process of universities will be successful when it will be based on such specific principles: professional axiological orientation; the unity of the theory of professional ethics and moral practice (professional morality); systematic formation of professional ethics; interdisciplinary in the formation of professional ethics; the unity of moral consciousness and moral activity; complementarity; integration and mutual influence of ethical and professional knowledge; designing of personal trajectory of formation; moral and ethical reflexive orientation of the process of teaching students of the specialty "Social Work"; moral choice; facilitation; academic integrity. Important are the general pedagogical principles: humanization and democratization, scientific, continuity, dynamism, personal activity. Also, the professional development of specialists at universities is influenced by generaldiplomatic principles: objectivity, connection theory with practice, systematic, visibility and variety of methods, strength of learning knowledge, skills and abilities.

Thus, the effectiveness of the process of forming the professional ethics of future specialists in social work is ensured by systematic interaction and complementary, general-didactic, general pedagogical and specific principles. They take into 
account moral and ethical norms of professional activity, professional culture and various educational forms of study at the university.

Keywords: professional ethics, social worker, university, specific principles, general pedagogical principles, general-didactic principles.

\section{ВСТУП}

Постановка проблеми. Реформи освітньої галузі сучасної України актуалізують питання покращення ефективності дії етичних стандартів у закладах вищої освіти, дотримання моральних норм і цінностей у взаєминах колективу академічного персоналу, студентів.

Упровадження моральних стандартів у освітній процес університетів, проведення паралелі 3 кращими взірцями академічної культури $€ C$, послідовне втілення всього інноваційного в наукове життя $€$ виявом прагнення вітчизняної спільноти взяти на себе відповідальність у захисті норм права і базових етичних цінностей, забезпеченні якості та належних результатів професійно-етичної підготовки фахівців соціальної роботи.

Учені суголосні в думці, що стратегію і тактику взаємодії викладачів та студентів, зміст і характер їхньої творчої співпраці визначають принципи навчального процесу в університеті.

Аналіз останніх досліджень і публікацій. До розгляду питання принципів професійно-етичної підготовки фахівців сучасні вчені підходять по-різному. Так, ними теоретично обґрунтовано специфічні принципи професійної етики, які виступають підґрунтям етичної рефлексії етико-прикладної сфери (А. Болдова, О. Дуб, А. Каленський, Л. Москальова, О. Пономаренко, Н. Сопнєва, Л. Хоружа та ін.). Дослідники розглядають загальні принципи формування професійної етики та моралі (Н. Год, О. Камінська, О. Кривошеєва, М. Михнюк, Т. Спіріна, Н. Тимченко, О. Хорошайло та ін.). Проте поза увагою залишились наукові висліди стосовно питання сучасних принципів формування професійної етики майбутніх соціальних працівників в університетах.

META I ЗАВДАННЯ ДОСЛІДЖЕНнЯ полягають у розкритті сучасних принципів, які будуть покладені в основу моделювання процесу формування професійної етики майбутніх соціальних працівників в університетах.

МЕТОДИ ДОслІДЖЕНня - теоретичний аналіз і узагальнення науково-педагогічної літератури з окресленої проблеми.

\section{РЕЗУЛЬТАТИ ДОСЛІДЖЕННЯ}

Ефективність професійно-етичної підготовки майбутніх соціальних працівників в університетах може забезпечити відповідна педагогічна система, що ґрунтуватиметься на певних формах, методах, інноваційних технологіях і принципах.

Аналіз сучасної науково-довідкової літератури дає можливість окреслити поняття «принцип». Останній трактується як: основа сукупності певних знань чи фактів, або нормативне твердження, яке веде до здійснення пізнавальної, практичної та духовної діяльності (Лебедев С. А., 2008, с. 509); морально-етичні засади, які скеровують поведінку людини; система знань, які взаємопов'язані між собою та створюють взаємовплив (Шинкарук В.І., 2002, с. 519); основне вихідне положення - підґрунтя всієї теоретичної системи наук (Тофтул М. Г., 2014, с. 307).

Отже, принципи формування професійної етики майбутніх соціальних працівників визначають мету, зміст, форми, методи, засоби і прийоми окресленого процесу, виступаючи такими педагогічними положеннями, на яких будується стратегія суб'єкт-суб'єктних взаємин в освітньому процесі університету.

Однак розгляд специфіки принципів не матиме наукового сенсу без аналізу етичних принципів, яких дотримуються фахівці в процесі діяльності. Тут послуговуватимемося базовими етичними принципами, виокремленими в Етичному кодексі спеціалістів із соціальної роботи (соціальних працівників і соціальних педагогів), прийнятому в Україні в 2003 р. Зосібна, маємо на меті вказати на такі з них, як повага до гідності кожної людини; пріоритетність інтересів клієнтів; толерантність; довіра та взаємодія у вирішенні проблем клієнта; доступність послуг; конфіденційність; дотримання норм професійної етики (Етичний кодекс спеціалістів із соціальної роботи України, 2003, с. 18). Також Глобальною декларацією етичних принципів соціальної роботи, запропонованою Міжнародною федерацією соціальних працівників та Міжнародною Асоціацією шкіл соціальної роботи, виокремлено дев'ять принципів взаємин фахівця з клієнтами та колегами: визнання гідності людини, дотримання прав людини, сприяння соціальній справедливості, сприяння праву на самовизначення, сприяння праву на участь, дотримання конфіденційності та приватності, ставлення до людей як до цілісних індивідів, етичне застосування технологій та соціальних медіа, професійна доброчесність ("Global Social Work Ethical Principles / IASSW ", 2018; " Global Social Work Ethical Principles / IFSW,", 2018).

До того ж, як вид професійної діяльності, соціальна робота зорієнтована на специфічні принципи: гуманізму, соціального реагування, комунікативності, варіативності соціальної допомоги, клієнтоцентризму, особистісного підходу, довіри до клієнта та підтримки довіри клієнта до соціального працівника, справедливості, толерантності, модальності (гнучкості), перманентності (неперервності), компетентності, конфіденційності, посередництва тощо (Пічі В.М., 2013, с. 323-324; 7, с. 357-359).

Наукові розробки спрямовані на визначення сучасних специфічних принципів формування професійної етики майбутніх соціальних працівників в університетах, таких, як: принципи професійно-аксіологічної спрямованості; єдності теорії професійної етики та моральної практики (фахової моральності); системності формування професійної етики; міждисциплінарності у формуванні професійної етики; єдності моральної свідомості й моральної діяльності; комплементарності; інтеграції і взаємовпливу етичного та професійного знання; проектування особистісної траєкторії формування; морально-етичної рефлексивної спрямованості 
процесу навчання студентів спеціальності «Соціальна робота»; морального вибору; фасилітації; академічної доброчесності (Зозуляк-Случик Р. В., 2018, с. 72).

Спробуємо здійснити їх короткий аналіз.

Принцип професійно-аксіологічної спрямованості орієнтує майбутніх соціальних працівників на професійноетичні цінності, інтеріоризацію моральних норм, ідеалів, правил, переконань і відтворення їх у власній поведінці, що формує позицію фахівця, готового до професійно-етичного вдосконалення та самовдосконалення.

Принцип єдності теорії професійної етики та моральної практики сприяє перенесенню професійноетичних знань, умінь і навичок майбутніх соціальних працівників у практичну площину. Адже істинність етичної теорії перевіряється емпірією (моральною практикою - моральністю), оскільки без емпіричних даних теорія залишається лише ідеєю. Цей принцип забезпечує створення ситуації морального вибору в контексті професійної діяльності і навчання студентів, спонукаючи робити моральний вибір, тобто вибір учинків, дій. Він має своє продовження в моральній практиці, тобто моральності. У даному випадку відбувається перетворення професійної діяльності в моральну рису майбутнього соціального працівника.

Принцип системності формування професійної етики сприяє набуттю знань, умінь і навичок із професійноетичної підготовки студентів у відповідній системі, між усіма елементами якої існує логічний взаємозв'язок.

У практичній площині він націлений на формування професійної компетентності шляхом вибору найбільш доцільних форм, методів, інноваційних технологій освіти в університеті.

Принцип міждисциплінарності в професійно-етичній підготовці забезпечує єдність організаційно-педагогічних вимог до змісту, форм і методів навчання студентів, сприяючи співпраці викладачів різних дисциплін, у тому числі «Етики соціальної роботи», задля підвищення рівня сформованості професійної етики майбутніх соціальних працівників в університетах.

Принцип єдності моральної свідомості й моральної діяльності полягає у формуванні морально-етичного знання, що виступає основою моральної свідомості особистості та є його відображенням у моральності, тобто моральній діяльності.

Принцип комплементарності, або додатковості, сприяє формуванню професійної етики майбутніх соціальних працівників через форми позааудиторної роботи, особливо волонтерську діяльність.

Принцип інтеграції і взаємовпливу етичного та професійного знання здійснюється на основі взаємозв'язків і взаємовпливу етичних і професійних знань, що реалізуються через засвоєння майбутніми соціальними працівниками категорій професійної етики та моралі.

Принцип проектування особистісної траєкторії формування сприяє ефективному особистісному професійному та моральному вдосконаленню майбутніх соціальних працівників, що спостерігається у засвоєнні професійно-етичних знань, умінь і навичок, формуванні моральних потреб, переконань, розвитку особистісноморальних професійно важливих якостей.

Принцип морально-етичної рефлексивної спрямованості процесу навчання морального вибору спонукає студентів до моральної оцінки своїх дій, власного морального вибору за критеріями, визначає моральний контекст професійного вирішення певної соціальної проблеми.

Принцип фасилітації допомагає майбутньому соціальному працівникові в його професійно-етичному зростанні в освітньому процесі університету.

Принцип академічної доброчесності виробляє особистісно-вольові професійно важливі риси студента, зокрема чесність, справедливість, повагу, відповідальність, мужність, які забезпечать високий рівень професіоналізму майбутніх фахівців соціальної роботи.

Формуванню професійної етики майбутніх соціальних працівників, крім специфічних принципів, сприяють і сучасні загальнопедагогічні принципи, які побудовані на положеннях: об'єктивності (сформовані на основі об'єктивно існуючих педагогічних закономірностей); орієнтованості (зорієнтовані на розв'язання відповідного рівня освітніх завдань, визначаючи тим самим загальну стратегію формування професійної етики); системності (виступають системотворним чинником); аспектності (розкривають можливості розробки та вдосконалення педагогічної системи формування професійної етики); доповненості (принципи взаємозбагачуються, не замінюючи один одного (Михнюк М. І., 2017, с. 167-68).

Аналіз наукових досліджень засвідчує, що до загальнопедагогічних принципів формування професійної етики майбутніх соціальних працівників в університетах можна віднести принципи гуманізації та демократизації, науковості, наступності і послідовності, безперервності, динамічності, особистої активності (Каленський А., Зозуляк-Случик Р., 2018, с. 120).

Так, принципи гуманізації та демократизації вимагає підходити до студента в освітньому процесі університету як до унікальної, неповторної особистості, котра прагне максимального саморозвитку та самоствердження, професійного становлення.

Принцип науковості сприяє засвоєнню студентами системи наукових знань через певні напрями: соціальну роботу як науку та практичну діяльність; особливості впливу соціуму на соціалізацію особистості, моральні концепції соціальної роботи; професійно-етичні цінності, норми поведінки і взаємин тощо.

Принцип наступності і послідовності встановлює логічну поетапність у формуванні професійної етики майбутніх соціальних працівників в університетах.

Принцип безперервності націлений на безперервний зв'язок усіх етапів формування студентів в освітньому процесі університетів, де основними чинниками розглядаються систематичне і поступове професійно-етичне вдосконалення та самовдосконалення, формування особистісно-моральних і професійно важливих якостей студентів. 
Принцип динамічності передбачає розвиток фахівця впродовж життя та переконує в потребі безперервного професійного зростання.

Принцип особистої активності сприяє розвитку суб'єктності в освітньому процесі університету. Тут ідеться про становлення такої особисті, котра самостійно обирає форми і методи власного професійного розвитку, що постають із власного бачення ідеалів, цінностей та моральних переконань.

\section{ВИСНОВКИ ТА ПЕРСПЕКТИВИ ПОДАЛЬШИХ ДОСЛІДЖЕНЬ}

Отже, можемо констатувати, що сучасними принципами професійно-етичної підготовки майбутніх соціальних працівників в університетах є специфічні (професійно-аксіологічної спрямованості; єдності теорії професійної етики та моральної практики (фахової моральності); системності формування професійної етики; міждисциплінарності у формуванні професійної етики; єдності моральної свідомості й моральної діяльності; комплементарності; інтеграції і взаємовпливу етичного та професійного знання; проектування особистісної траєкторії формування; морально-етичної рефлексивної спрямованості процесу навчання студентів спеціальності «Соціальна робота»; морального вибору; фасилітації; академічної доброчесності) та загальнопедагогічні (гуманізації й демократизації, науковості, наступності і послідовності, безперервності, динамічності, особистої активності).

Подальшого дослідження потребує визначення ролі окреслених принципів у створенні педагогічної системи формування професійної етики майбутніх соціальних працівників в університетах.

\section{СПИСОК ВИКОРИСТАНИХ ДЖЕРЕЛ}

Пічі, В.М. (Наук.ред) (2013) Все про соціальну роботу : навч. енциклопед. словник-довідник. Львів : «Новий Світ - 2000». Етичний кодекс спеціалістів із соціальної роботи України. (2003) Соціальна політика і соціальна робота, 1, С. 16-22.

Зозуляк-Случик, Р. В. (2018) Специфічні принципи формування професійної етики майбутніх соціальних працівників в університетах. Актуальні питання гуманітарних наук : міжвуз. зб. наук. праць молод. вчен. Дрогобицького держ. пед. ун-ту імені Івана Франка Ред.-упоряд. В. Ільницький, А. Душний, І. Зимомря. Дрогобич: Посвіт. Вип. 18. С. 71-77.

Каленський, А., \&Зозуляк-Случик, Р. (2018) Основні принципи формування професійно-етичної компетентності майбутніх фахівців соціальної роботи в університетах. Formation of Modern Specialist's Professional Competence in the Context of European Integration: collection of scientific papers. ed. S. Arkhipova. Cherkasy : Bohdan Khmelnytskee National University at Cherkasy. C. 117-128.

Лебедев, С. А. (2008) Философия науки: краткая энциклопедия (основные направления, концепции, категории). Москва : Академический проект.

Михнюк, М. І. (2017) Теоретичні і методичні основи розвитку професійної культури викладачів спеціальних дисциплін будівельного профілю (Дис. ... д-ра пед. наук ). Інститут професійно-технічної освіти НАПН України. Київ.

Соціальна робота : короткий енциклопед. словник. (2002). Київ : ДЦССМ.

Тофтул, М. Г. (2014) Сучасний словник з етики. Житомир. Вид-во ЖДУ ім. І. Франка.

Шинкарук, В.І. (Ред.) (2002) Філософський енциклопедичний словник. Київ : Абрис.

Global Social Work Ethical Principles / IASSW (2018) Retrived from https://www.iassw-aiets.org/2018/04/18/ global-social-work-statement-of-ethical-principles-iass.

Global Social Work Ethical Principles / IFSW (2018) Retrived from https://www.ifsw.org/global-social-work-statement-of-ethicalprinciples.

\section{REFERENCES}

Pichi, V.M. (Ed.) (2013) Vse pro sotsialnu robotu: navch. entsykloped. slovnyk. L'viv: «Novyy Svit - 2000».

Etychnyi kodeks spetsialistiv iz sotsialnoi roboty Ukrainy (2003) Sotsialna polityka i sotsialna robota, 1, PP. 16-22.

Zozuliak-Sluchyk, R. V. (2018) Spetsyfichni pryntsypy formuvannia profesiinoi etyky maibutnikh sotsialnykh pratsivnykiv v universytetakh. Aktualni pytannia humanitarnykh nauk : mizhvuz. zb. nauk. prats molod. vchen. Drohobytskoho derzh. ped. un-tu imeni Ivana Franka In. Red-uporiad. V. Inytskyi, A. Dushnyi, I. Zymomria. Drohobych: Posvit, 18. PP. 71-77.

Kalenskyi, A., \&Zozuliak-Sluchyk R. (2018) Osnovni pryntsypy formuvannia profesiino-etychnoi kompetentnosti maibutnikh fakhivtsiv sotsialnoi roboty v universytetakh Formation of Modern Specialists Professional Competence in the Context of European Integration: collection of scientific papers. Ed. S. Arkhipova. Cherkasy : Bohdan Khmelnytskee National University at Cherkasy. PP. 117-128.

Lebedev, S. A. (2008) Filosofiya nauki: kratkaya entsiklopediya (osnovnyye napravleniya. kontseptsii. kategorii) Moskva : Akademicheskiy proyekt.

Mykhnyuk, M. I. (2017) Teoretychni i metodychni osnovy rozvytku profesiynoyi kul'tury vykladachiv spetsial'nykh dystsyplin budivel'noho (Extended abstract of candidate's thesis.) Instytut profesiyno-tekhnichnoyi osvity NAPN Ukrayiny. Kyiv.

Sotsial'na robota: korotkyy entsykloped. slovnyk (2002) Kyjiv: DTsSSM.

Toftul, M. H. (2014) Suchasnyi slovnyk z etyky (Modern Dictionary of Ethics). Zhytomyr : Vyd-vo ZhDU im. I. Franka

Shynkaruk, : V. I. (Ed.) (2002) Filosofskyi entsyklopedychnyi slovnyk. Abrys.

Global Social Work Ethical Principles / IASSW (2018) Retrived from https://www.iassw-aiets.org/2018/04/18/ global-social-work-statement-of-ethical-principles-iass..

Global Social Work Ethical Principles / IFSW (2018) Retrived from https://www.ifsw.org/global-social-work-statement-of-ethicalprinciples. 